\title{
MODEL MANAJEMEN BERBASIS SEKOLAH
}

\author{
Oleh: Abdul Hafid*
}

\begin{abstract}
The existence of the National Constitution on local government contributes to educational management model. The former centralized education has become decentralized. This leads to the growth of school based management. The purpose of this is to empower human resources, in particular to the head masters, teachers, administrative staff members, students and their parents, and the local community. They are empowered by giving them authority, and flexibility to handle the issues faced by the respective school. In short, school based management is more transparent and accountable, community involvement, active, creative, effective and enjoyable learning.
\end{abstract}

KEYWORDS: management, school, decentralization.

ERA desentralisasi pendidikan telah membawa perubahan-perubahan mendasar dalam berbagai kehidupan termasuk kehidupan pendidikan. Salah satu perubahan mendasar yang sedang digulirkan saat ini adalah manajemen negara, yaitu dari manajemen berbasis pusat menjadi manajemen berbasis daerah. Secara resmi, perubahan manajemen ini telah diwujudkan dalam bentuk "Undang-Undang Republik Indonesia Nomor 22 Tahun 1999 tentang Pemerintah Daerah" yang kemudian diikuti pedoman pelaksanaannya berupa "Peraturan Pemerintah Republik Indonesia Nomor 25 Tahun 2000 tentang Kewenangan Pemerintah dan Kewenangan Propinsi sebagai Daerah Otonomi. Konsekuensi logis dari undang-undang dan peraturan pemerintah tersebut adalah bahwa manajemen pendidikan harus disesuaikan dengan jiwa dan semangat otonomi. Karena itu, manajemen pendidikan berbasis pusat selama ini dipraktekkan perlu diubah menjadi manajemen berbasis sekolah (MBS). ${ }^{1}$

Selain alasan normatif, secara empirik MBS memang perlu diterapkan karena di lapangan menunjukkan kenyataan-kenyataan sebagai berikut:

1. Manajemen berbasis pusat selama ini telah memiliki banyak kelemahan, antara lain: keputusan pusat sering kurang sesuai dengan kebutuhan

*Peraih Magister Pendidikan dari Universitas Negeri Makassar (UNM) ini adalah Dosen pada Sekolah Tinggi Agama Islam (STAI) DDI Maros Sulawesi Selatan. 
sekolah; administrasi berlebihan yang dikarenakan lapis-lapis birokrasi yang terlalu banyak telah menyebabkan kelambanan dalam menangani setiap permasalahan, sehingga menyebabkan kurang optimalnya kinerja sekolah; dalam kenyataan, administrasi telah mengendalikan kreasi; proses pendidikan dijalankan dengan undermanaged sehingga menghasilkan tingkat efektivitas dan efisiensi yang rendah; pendekatan sarwa-negara (state-driven) telah menempatkan sekolah pada posisi yang marginal, sehingga sekolah tidak memiliki keberanian moral (prakarsa) untuk berinisiatif; sekolah tidak mandiri; terjadi penyumbatan dan bahkan pemasungan demokrasi; sekolah tidak peka dan jeli dalam menangkap dan mengungkap permasalahan, kebutuhan, dan aspirasi pendidikan dari masyarakat; dan manajemen berbasis pusat tidak saja menumpulkan daya kreativitas sekolah, tetapi juga mengikis habis rasa kepemilikan warga sekolah terhadap sekolahnya.

2. Sekolah paling memahami permasalahan di sekolahnya. Karena itu, sekolah merupakan unit utama yang harus memecahkan permasalahannya melalui sejumlah keputusan yang dibuat "sedekat" mungkin dengan kebutuhan sekolah. Untuk itu, sekolah harus memiliki kewenangan (otonomi), tidak saja dalam pengambilan keputusan, akan tetapi justru dalam mengatur dan mengurus kepentingan sekolah menurut prakarsa sendiri berdasarkan aspirasi warga sekolah sesuai dengan payung kebijakan makro pendidikan nasional.

3. Perubahan di sekolah akan terjadi jika semua warga sekolah ada "rasa memiliki" yang berasal dari kesempatan berpartisipasi dalam merumuskan perubahan dan keluwesan untuk mengadaptasikannya terhadap kebutuhan individu sekolah. Rasa memiliki ini pada gilirannya akan meningkatkan pula rasa tanggung jawab. Jadi, makin besar tingkat partisipasi warga sekolah dalam pengambilan keputusan, makin besar rasa memiliki terhadap sekolah, dan makin besar pula rasa tanggung jawabnya. Yang demikian ini berarti bahwa "perubahan" lebih disebabkan oleh dorongan internal sekolah dari pada tekanan dari luar sekolah.

4. Telah lama pengaturan yang bersifat birokratik lebih dominan dari pada tanggung jawab profesional, sehingga kreativitas sekolah pada umumnya dan guru pada khususnya terpasung dan bahkan terbunuh. Tidak jarang pula dijumpai bahwa formalitas sering jauh melampaui hakiki. Yang lebih parah lagi guru-guru kehilangan "jiwa kependidikannya". Mendidik tidak lebih dari sekadar pengenalan nilai-nilai, yang hasilnya hanya berupa pengetahuan nilai (logos) dan belum sampai pada penghayatan nilai (etos), apalagi sampai pengamalannya. Akibatnya, menurut Aburizal Bakrie, proses belajar mengajar di sekolah lebih memen- 
tingkan jawaban baku yang dianggap benar oleh guru, dibanding daya kreasi, nalar, dan eksperimentasi peserta didik untuk menemukan kemungkinan-kemungkinan baru. Tidak ada keterbukaan dan demokrasi. Tidak ada toleransi pada kekeliruan akibat kreativitas berpikir, karena yang benar adalah apa yang dipersepsikan benar oleh guru, sehingga yang terjadi hanyalah memorisasi dan "recall" dan tidak dihargainya kreativitas dan kemampuan peserta didik. Padahal, pembelajaran yang sebenarnya semestinya lebih mementingkan pada proses "pencarian jawaban" dibanding "memiliki jawaban".2

\section{PENGERTIAN}

Istilah manajemen berbasis sekolah (MBS) berasal dari tiga kata, yaitu manajemen, berbasis, dan sekolah. Manajemen adalah pengkoordinasian dan penyerasian sumber daya melalui sejumlah input manajemen untuk mencapai tujuan atau untuk memenuhi kebutuhan pelanggan. Catatan: sumber daya terbagi menjadi sumber daya manusia dan sumber daya selebihnya (peralatan, perlengkapan, bahan/material, dan uang); input manajemen terdiri dari tugas, rencana, program, limitasi yang terwujud dalam bentuk ketentuan-ketentuan. ${ }^{3}$

Berbasis berarti "berdasarkan pada" atau "berfokuskan pada". Sekolah adalah suatu organisasi terbawah dalam jajaran Departemen Pendidikan Nasional (Depdiknas) yang bertugas memberikan "bekal kemampuan dasar" kepada peserta didik atas dasar ketentuan-ketentuan yang bersifat legalistik (makro, meso, mikro) dan profesionalistik (kualifikasi, untuk sumber daya manusia; spesifikasi untuk barang/jasa, dan prosedur-prosedur kerja).

Otonomi dapat diartikan sebagai kewenangan/kemandirian yaitu kemandirian dalam mengatur dan mengurus dirinya sendiri, dan merdeka/tidak tergantung. ${ }^{4}$ Istilah otonomi juga sama dengan istilah "swa", misalnya swasembada, swakelola, swadana, swakarya, swalayan, dan swaswa lainnya. Jadi otonomi sekolah adalah kewenangan sekolah untuk mengatur dan mengurus kepentingan warga sekolah menurut prakarsa sendiri berdasarkan aspirasi warga sekolah sesuai dengan peraturan perundang-undangan pendidikan nasional yang berlaku. Tentu saja kemandirian yang dimaksud harus didukung oleh sejumlah kemampuan, yaitu kemampuan mengambil keputusan yang terbaik, kemampuan berdemokrasi/menghargai perbedaan pendapat, kemampuan memobilisasi sumber daya, kemampuan memilih cara pelaksanaan yang terbaik, kemampuan berkomunikasi yang efektif, kemampuan memecahkan persoalan-persoalan sekolah, kemampuan adaptif dan antisipatif, kemampuan bersinergi dan berkolaborasi, dan kemampuan memenuhi kebutuhannya sendiri. 
Untuk mencapai otonomi sekolah, diperlukan suatu proses yang disebut "desentralisasi". Desentralisasi adalah penyerahan wewenang pemerintahan pendidikan dari pemerintah pusat kepada pemerintah daerah, dari pemeritah Dati I ke Dati II, dari Dati II ke sekolah, dan bahkan dari sekolah ke guru, tetapi harus tetap dalam kerangka pendidikan nasional. Pengalaman selama ini menunjukkan pendidikan yang diatur secara "sentralistik" menghasilkan fenomena-fenomena seperti berikut: lamban berubah/beradaptasi, bersifat kaku, normatif sekali orientasinya karena terlalu banyaknya lapis-lapis birokrasi, tidak jarang birokrasi mengendalikan fungsi dan bukan sebaliknya, uniformitas telah memasung kreativitas, dan tradisi serta serimoni yang penuh kepalsuan sudah menjadi kebiasaan. Kecil itu indah, adalah merupakan esensi desentralisasi. Menurut Bailey, organisasi yang cakupan, pemerintahan, manajemen, dan ukurannya kecil, mudah beradaptasi. ${ }^{5}$ Karena itu, desentralisasi bukan lagi merupakan hal penting untuk diterapkan, tetapi sudah merupakan keharusan. Dengan desentralisasi, maka: (1) fleksibilitas pengambilan keputusan sekolah akan tumbuh dan berkembang dengan subur, sehingga keputusan dibuat "sedekat" mungkin dengan kebutuhan sekolah; (2) akuntabilitas/pertanggung jawaban terhadap masyarakat (majelis sekolah, orang tua peserta didik, publik) dan pemerintah meningkat; dan (3) kinerja sekolah akan meningkat (efektivitasnya, kualitasnya, efisiensinya, produktivitasnya, inovasinya, provitabilitasnya, kualitas kehidupan kerjanya, dan moralnya).

Pengambilan keputusan partisipatif adalah suatu cara untuk mengambil keputusan melalui penciptaan lingkungan yang terbuka dan demokratik, dimana warga sekolah (guru, siswa, karyawan, orang tua siswa, tokoh masyarakat) didorong untuk terlibat secara langsung dalam proses pengambilan keputusan yang akan dapat berkontribusi terhadap pencapaian tujuan sekolah. ${ }^{6}$ Hal ini dilandasi oleh keyakinan bahwa jika seseorang dilibatkan (berpartisipasi) dalam pengambilan keputusan, maka yang bersangkutan akan ada "rasa memiliki" terhadap keputusan tersebut, sehingga yang bersangkutan juga akan bertanggung jawab dan berdedikasi sepenuhnya untuk mencapai tujuan sekolah. Singkatnya: makin besar tingkat pertisipasi, makin besar pula rasa memiliki; makin besar rasa memiliki, makin besar pula rasa tanggung jawab; dan makin besar rasa tanggung jawab, makin besar pula dedikasinya. Tentu saja pelibatan warga sekolah dalam pengambilan keputusan harus mempertimbangkan keahlian, yurisdiksi, dan relevansinya dengan tujuan pengambilan keputusan sekolah.

Dengan pengertian di atas, maka pengembangan manajemen berbasis sekolah semestinya mengakar di sekolah, terfokus di sekolah, terjadi di sekolah, dan dilakukan oleh sekolah. Untuk itu, penerapan manajemen berbasis sekolah memerlukan konsolidasi manajemen sekolah. 


\section{TUJUAN}

Manajemen berbasis sekolah bertujuan untuk "memberdayakan" sekolah, terutama sumber daya manusianya (kepala sekolah, guru, karyawan, siswa, orang tua siswa, dan masyarakat sekitarnya), melalui pemberian kewenangan, fleksibilitas, dan sumber daya lain untuk memecahkan persoalan yang dihadapi oleh sekolah yang bersangkutan.

Ciri-ciri sekolah yang "berdaya" pada umumnya: tingkat kemandirian tinggi/tingkat ketergantungan rendah; bersifat adaptif dan antisipatif/proaktif sekaligus; memiliki jiwa kewirausahaan tinggi (ulet, inovatif, gigih, berani mengambil resiko, dan sebagainya); bertanggung jawab terhadap hasil sekolah; memiliki kontrol yang kuat terhadap input manajemen (T,R,P,L,T3,K) dan sumber dayanya; kontrol terhadap kondisi kerja; komitmen yang tinggi pada dirinya; dan dinilai oleh pencapaian prestasinya. Selanjutnya, bagi sumber daya manusia sekolah yang berdaya, pada umumnya, memiliki ciri-ciri: pekerjaan adalah miliknya, dia bertanggung jawab, dia memiliki suara bagaimana sesuatu dikerjakan, pekerjaannya memiliki kontribusi, dia tahu posisinya dimana, dia memiliki kontrol terhadap pekerjaannya, dan pekerjaannya merupakan bagian hidupnya.

Contoh-contoh tentang hal-hal yang dapat memberdayakan warga sekolah adalah: pemberian tanggung jawab, pekerjaan yang bermakna, memecahkan masalah pekerjaan secara "team work", variasi tugas, hasil kerja yang terukur, kemampuan untuk mengukur kinerjanya sendiri, tantangan, kepercayaan, didengar, ada pujian, menghargai ide-ide, mengetahui bahwa dia adalah bagian penting dari sekolah, kontrol yang luwes, dukungan, komunikasi yang efektif, umpan balik bagus, sumber daya yang dibutuhkan ada, dan warga sekolah diberlakukan sebagai manusia ciptaan-Nya yang memiliki martabat tertinggi. ${ }^{7}$

\section{PERGESERAN PENDEKATAN MANAJEMEN PENDIDIKAN}

Seiring dengan berlakunya Undang-Undang Republik Indonesia Nomor 22 Tahun 1999 tentang Pemerintahan Daerah (Otonomi Daerah) dan bukti-bukti empirik tentang kurang efektif dan efisiensinya manajemen berbasis pusat, maka Departemen Pendidikan Nasional melakukan penyesuaian-penyesuaian, salah satunya adalah melakukan pergeseran pendekatan manajemen, yaitu dari pendekatan manajemen berbasis pusat menjadi manajemen berbasis sekolah. ${ }^{8}$

Berikut disampaikan penjelasan terhadap pergeseran pendekatan manajemen berbasis pusat menuju MBS. 


\section{Dari Sub-Ordinasi Menuju Otonomi}

Pada manajemen berbasis pusat, sekolah merupakan sub-ordinasi dari pusat, sehingga sifat ketergantungannya sangat tinggi. Sekolah tidak berdaya dan tidak memiliki kemandirian, sehingga kreativitas dan prakarsanya terpasung dan beku. Pada MBS, sekolah memiliki otonomi (kemandirian) untuk berbuat yang terbaik bagi sekolahnya. Ketergantungan pada tingkat pusat makin kecil, sehingga sekolah harus dewasa dan meyakini bahwa perubahan pendidikan tidak akan terjadi jika sekolahnya sendiri tidak berubah. Tentu saja kemandirian ini menuntut kemampuan sekolah untuk mengatur dan mengurus sekolahnya menurut prakarsanya sendiri berdasarkan aspirasi warga sekolah sesuai dengan peraturan perundang-undangan yang berlaku.

\section{Dari Pengambilan Keputusan Terpusat Menuju Pengambilan Keputusan Partisipatif}

Berbeda dengan pengambilan keputusan pada manajemen berbasis pusat yang ditandai oleh one man show, lamban hasilnya, dan sering tidak pas hasilnya dengan kebutuhan sekolah, maka pengambilan keputusan pada MBS melibatkan warga sekolah, yang selain cepat hasilnya, juga sesuai hasilnya dengan kebutuhan sekolah. Pelibatan partisipan dalam pengambilan keputusan tentu saja disesuaikan dengan relevansi, keahlian, yurisdiksi, dan kompatibilitas keputusan dengan kepentingan partisipan.

\section{Dari Ruang Gerak Kaku Menuju Ruang Gerak Luwes}

Akibat banyaknya tugas dan fungsi, wewenang, tanggung jawab, kewajiban dan hak sekolah yang ditangani oleh Pusat, Wilayah, dan Kandep, maka ruang gerak sekolah kaku untuk menyelesaikan masalah-masalah yang dihadapi maupun untuk memenuhi kebutuhannya. Pada pendekatan manajemen yang baru, ruang gerak sekolah sangat luwes karena apa yang selama ini dilakukan oleh Pusat, Wilayah, dan Kandep, sebagian besar kini diserahkan ke sekolah.

\section{Dari Pendekatan Birokrasi Menuju Pendekatan Profesionalisme}

Pada pendekatan birokrasi, apa yang dilakukan oleh sekolah didasarkan atas apa yang dianggap benar dan baik oleh pimpinannya. Pada pendekatan profesionalisme, apa yang dilakukan oleh sekolah didasarkan atas profesionalisme. Karena itu, peranan keahlian sangat penting dalam membimbing tingkah laku warga sekolah, bukan kekuasaan. 


\section{Dari Manajemen Sentralistik Menuju Manajemen Desentralistik}

Pada model lama, pusat memiliki kewenangan yang berlebihan, sehingga terjadilah pemusatan kekuasaan di pusat. Pemusatan kekuasaan ini telah menimbulkan dampak negatif pada sekolah, yaitu selain sekolah tidak berdaya, banyak keputusan-keputusan yang tidak efektif dan efisien. Karena kecil kewenangan yang dimiliki oleh sekolah, maka tidak jarang sekolah acuh tak acuh terhadap masalah-masalah yang dihadapi. Sedang pada manajemen desentralistik, banyak kewenangan Pusat, Wilayah, dan Kandep yang diserahkan ke sekolah. Dengan pendekatan ini, maka sekolah akan lebih berdaya dan keputusan-keputusan yang dibuatnya akan lebih efektif dan efisien.

\section{MODEL MBS IDEAL}

Dalam artian yang sesungguhnya, sebenarnya sulit memberikan contoh manajemen berbasis yang "uniformitas" dan "konformitas" sekaligus, karena dalam kenyataan juga tidak mudah menemukan sekolah yang karakteristik "kancah"nya sama. Model MBS berikut merupakan model yang pada umumnya memiliki ciri-ciri universal, sehingga setiap sekolah yang akan mengadopsi model ini perlu mengadaptasikannya/menyesuaikannya dengan karakteristik kancah di sekolah masing-masing. Model MBS berikut pada dasarnya ditampilkan menurut pendekatan sistem (berpikir sistem), yaitu output-proses-input. Urutan ini dipilih dengan alasan bahwa setiap kegiatan sekolah akan dilakukan, termasuk kegiatan melakukan analisis SWOT (Strength, Weakness, Opportunity, and Threat), semestinya dimulai dari "output" yang akan dicapai, kemudian ke "proses", dan baru ke "input" yang dibutuhkan untuk berlangsungnya proses. Namun, langkahlangkah pemecahan persoalannya ditempuh dengan mengikuti urutan yang berlawanan dengan arah analisis SWOT.

Karena MBS telah merupakan jiwa dan semangat sekolah, maka setiap penjelasan berikut telah menginklusifkan otonomi dan partisipasi ke dalamnya, meskipun tanpa menyebut istilah otonomi dan partisipasi. Artinya, setiap pembahasan butir-butir berikut selalu dijiwai oleh otonomi dan partisipasi dalam pengambilan keputusan sekolah. Secara ringkas, MBS dapat diuraikan seperti berikut: ${ }^{9}$

Efektivitas adalah ukuran yang menyatakan sejauhmana sasaran (kuantitas, kualitas, waktu) telah dicapai. Dalam bentuk persamaan, efektivitas sama dengan hasil nyata dibagi hasil yang diharapkan.

Kualitas adalah gambaran dan karakteristik menyeluruh dari barang atau jasa, yang menunjukkan kemampuannya dalam memuaskan kebu- 
tuhan yang ditentukan atau yang tersirat. Mutu barang atau jasa dipengaruhi oleh banyak tahapan kegiatan yang saling berhubungan seperti desain, operasi produk atau jasa dan pemeliharaannya.

Produktivitas adalah hasil perbandingan antara output dibagi input. Baik output maupun input adalah dalam bentuk kuantitas. Kuantitas input berupa tenaga kerja, modal, bahan, dan energi. Kuantitas output dapat berupa jumlah barang atau jasa, tergantung pada jenis pekerjaan.

\section{PROSES PENGAMBILAN KEPUTUSAN}

Proses pengambilan keputusan partisipatif merupakan salah satu "inti" MBS. Esensi proses pengambilan keputusan partisipatif adalah untuk mencari "wilayah kesamaan" antara kelompok-kelompok kepentingan yang terkait dengan sekolah (stakehorder) yaitu kepala sekolah, guru, siswa, orangtua siswa, dan pemerintah/yayasan)..$^{10}$ Wilayah kesamaan inilah yang menjadi modal dasar untuk menumbuhkan "rasa memiliki" bagi semua kelompok kepentingan yang terkait dengan sekolah dan ini dapat dilakukan secara efektif melalui pelibatan semua kelompok kepentingan dalam proses pengambilan keputusan. Pelibatan kelompok kepentingan dalam proses pengambilan keputusan harus mempertimbangkan keahlian, yurisdiksi, dan relevansinya dengan tujuan pengambilan keputusan.

Menurut Cangemi, paling tidak ada tiga pertanyaan yang harus dijawab oleh kepala sekolah sewaktu akan menerapkan pengambilan keputusan partisipatif: (1) bagaimana cara menentukan, dalam setiap kasus, apakah cocok dan produktif jika pengambilan keputusan melibatkan kelompok-kelompok kepentingan?; (2) kemudian, jika proses pengambilan keputusan perlu melibatkan kelompok-kelompok kepentingan, pertanyaan kedua adalah: bagian yang mana dari proses pengambilan keputusan yang perlu melibatkan kelompok-kelompok kepentingan?; (3) pertanyaan ketiga adalah cara yang mana (apa) yang paling efektif untuk melibatkan mereka dalam proses pengambilan keputusan?.11

Tentunya tidak semua wilayah (zona) pengambilan keputusan harus melibatkan semua kelompok kepentingan. Ada wilayah-wilayah yang memang merupakan hak prerogatif pimpinan untuk diputuskan secara sendirian dan bawahan harus menerimanya tanpa syarat. Kalaupun pimpinan melibatkan kelompok-kelompok kepentingan, maka hal ini harus dipikirkan secara mendalam dan terkontrol pelaksanaannya.

Ada empat petunjuk untuk mengidentifikasi pengambilan keputusan yang harus melibatkan para kelompok kepentingan, yaitu relevansi, kom- 
petensi, yurisdiksi, dan kompatibilitas tujuan. Pertama, adalah tingkat relevansinya. Sekiranya keputusan yang akan diambil relevan dengan kebutuhan kelompok kepentingan tertentu (kelompok yang bakal terkena dampak keputusan), maka pengambilan keputusan sebaiknya melibatkan kelompok kepentingan tersebut. Kedua, adalah uji keahlian. Artinya, kelompok kepentingan yang akan berpartisipasi dalam pengambilan keputusan, harus memiliki sesuatu untuk dikontribusikan. Mereka harus memiliki kompetensi untuk ikut serta dalam memecahkan persoalan-persoalan yang terkait dengan kepentingannya. Ketiga, uji yurisdiksi. Sekolah didirikan untuk menjalankan fungsinya melalui struktur-herarkis. Karena itu, ada batas-batas yurisdiksi yang memang tidak semua kelompok kepentingan harus terlibat dalam pengambilan keputusan. Pelibatan yang tidak proporsional secara yurisdiksi akan cenderung membuat frustasi dan kemarahan yang tidak berdasar. Keempat, uji kompatibilitas tujuan. Apabila kompatibilitas tujuan dari semua kelompok kepentingan diinginkan, maka pelibatan mereka dalam proses pengambilan keputusan sangat diperlukan kepala sekolah mengatur dan mengurus sekolahnya melalui sejumlah input manajemen. Kelengkapan dan kejelasan input manajemen akan membatu kepala sekolah mengelola sekolahnya dengan baik. Berikut adalah sejumlah input manajemen, seperti yang dikemukakan oleh Poernomosidi Hadjisarosa $^{12}$ dengan keterangan seperlunya:

\section{Tugas}

Kepala sekolah harus jelas memberikan tugas-tugas kepada bawahannya, yang dilengkapi ketentuan-ketentuan mengenai fungsi, wewenang, tanggung jawab, kewajiban dan hak.

\section{Rencana}

Rencana/rancang-bangun adalah diskripsi produk untuk keperluan pembuatan/pembangunan (diskripsi disebut kualifikasi untuk sumber daya manusia, spesifikasi untuk sumberdaya selain sumber daya manusia). Rencana juga mengandung isi diskripsi kegiatan untuk keperluan penyelenggaraan, dalam arti, cukup lengkap untuk berlangsung. Dalam pendidikan, rencana yang dimaksud adalah rencana pengembangan sekolah.

\section{Program}

Program adalah alokasi sumber daya ke dalam kegiatan-kegiatan, menurut jadwal-waktu dan menunjukkan tata laksana yang sinkron. Dengan kata lain program adalah bentuk dokumen untuk menggambarkan langkah-langkah untuk mewujudkan sinkronisasi dalam ketatalaksanaan, sebagai salah satu konsekuensi dari koordinasi. 


\section{Limitasi/Ketentuan-Ketentuan}

Input manajemen yang menyangkut limitasi, yaitu yang muncul dalam berbagai bentuk ketentuan, seperti yang menyangkut kualifikasi, spesifikasi dan metoda ataupun prosedur, manual, dan peraturan-perundangan. Input manajemen yang berupa limitasi ini pada dasarnya merupakan aturan main atau rule of the game yang perlu diikuti oleh semua warga sekolah agar pengembangan sekolah berjalan lancar untuk mencapai tujuannya.

\section{Pengendalian/Tindakan Turun Tangan}

Input manajemen yang menyangkut pengendalian/pengawasan, yaitu yang muncul dalam wujud Tindakan Turun Tangan (T3), untuk meyakinkan bahwa tujuan/sasaran sekolah yang telah ditetapkan dapat dicapai secara efektif dan efisien.

\section{Strategi Pelaksanaan Manajemen Berbasis Sekolah}

Pada dasarnya, mengubah pendekatan manajemen berbasis pusat menjadi manajemen berbasis sekolah bukanlah merupakan one-shot and quick-fix, akan tetapi merupakan proses yang berlangsung secara terus menerus dan melibatkan semua unsur yang bertanggung jawab dalam penyelenggaraan pendidikan persekolahan. Oleh karena itu, menurut Slamet $\mathrm{PH},{ }^{13}$ strategi utama yang perlu ditempuh dalam melaksanakan manajemen berbasis sekolah adalah sebagai berikut:

a. Menyosialisasikan konsep manajemen berbasis sekolah ke seluruh warga sekolah, yaitu guru, siswa, wakil-wakil kepala sekolah, konselor, karyawan dan unsur-unsur terkait lainnya (orang tua murid, pengawas, wakil kandep, wakil kanwil, dan sebagainya) melalui seminar, diskusi, forum ilmiah, dan media masa. Hendaknya dalam sosialisasi ini juga dibaca dan dipahami sistem, budaya, dan sumber daya sekolah yang ada secermat-cermatnya dan direfleksikan kecocokannya dengan sistem, budaya, dan sumber daya yang dibutuhkan untuk penyelenggaraan manajemen berbasis sekolah.

b. Melakukan analisis situasi sekolah dan luar sekolah yang hasilnya berupa tantangan nyata yang harus dihadapi oleh sekolah dalam rangka mengubah manajemen berbasis pusat menjadi manajemen berbasis sekolah. Tantangan adalah selisih (ketidaksesuaian) antara keadaan sekarang (manajemen berbasis pusat) dan keadaan yang diharapkan (manajemen berbasis sekolah). Karena itu, besar kecilnya ketidaksesuaian antara keadaan sekarang (kenyataan) dan keadaan yang diharapkan (idealnya) memberitahukan besar kecilnya tantangan (loncatan). 
c. Merumuskan tujuan situasional yang akan dicapai dari pelaksanaan manajemen berbasis sekolah berdasarkan tantangan nyata yang dihadapi (butir 2). Segera setelah tujuan situasional ditetapkan, kriteria kesiapan setiap fungsi dan faktor-faktornya ditetapkan. Kriteria inilah yang akan digunakan sebagai standar atau kriteria untuk mengukur tingkat kesiapan setiap fungsi dan faktor-faktornya.

d. Mengidentifikasi fungsi-fungsi yang perlu dilibatkan untuk mencapai tujuan situasional dan yang masih perlu diteliti tingkat kesiapannya. Untuk mencapai tujuan situasional yang telah ditetapkan, maka perlu diidentifikasi fungsi-fungsi mana yang perlu dilibatkan untuk mencapai tujuan situasional dan yang masih perlu diteliti tingkat kesiapannya. Fungsi-fungsi yang dimaksud meliputi antara lain: pengembangan kurikulum, pengembangan tenaga kependidikan dan nonkependidikan, pengembangan siswa, pengembangan iklim akademik sekolah, pengembangan hubungan sekolah-masyarakat, pengembangan fasilitas, dan fungsi-fungsi lain.

e. Menentukan tingkat kesiapan setiap fungsi dan faktor-faktornya melalui analisis SWOT (Strength, Weaknes, Opportunity, and Threat). dilakukan dengan maksud mengenali tingkat kesiapan setiap fungsi dari keseluruhan fungsi yang diperlukan untuk mencapai tujuan situasional yang telah ditetapkan. Analisis SWOT dilakukan terhadap keseluruhan faktor dalam setiap fungsi, baik faktor yang tergolong internal maupun eksternal. yang dinyatakan sebagai: kekuatan, bagi faktor yang tergolong internal; peluang, bagi faktor yang tergolong faktor eksternal. Sedang tingkat kesiapan yang kurang memadai, artinya tidak memenuhi ukuran kesiapan, dinyatakan bermakna: kelemahan, bagi faktor yang tergolong faktor internal; dan ancaman, bagi faktor yang tergolong faktor eksternal.

f. Memilih langkah-langkah pemecahan (peniadaan) persoalan, yakni tindakan yang diperlukan untuk mengubah fungsi yang tidak siap menjadi fungsi yang siap. Selama masih ada persoalan, yang sama artinya dengan ada ketidaksiapan fungsi, maka tujuan situasional yang telah ditetapkan tidak akan tercapai. Oleh karena itu, agar tujuan situasional tercapai, perlu dilakukan tindakan-tindakan yang mengubah ketidaksiapan menjadi kesiapan fungsi. Tindakan yang dimaksud lazimnya disebut langkah-langkah pemecahan persoalan, yang hakekatnya merupakan tindakan mengatasi makna kelemahan dan/atau ancaman, agar menjadi kekuatan dan/atau peluang, yakni dengan memanfaatkan adanya satu/lebih faktor yang bermakna kekuatan dan/atau peluang. 
g. Berdasarkan langkah-langkah pemecahan persoalan tersebut, sekolah bersama-sama dengan semua unsur-unsurnya membuat rencana untuk jangka pendek, menengah, dan panjang, beserta program-programnya untuk merealisasikan rencana tersebut. Sekolah tidak selalu memiliki sumber daya yang cukup untuk melaksanakan manajemen berbasis sekolah idealnya, sehingga perlu dibuat sekala prioritas.

\section{SIMPULAN}

Mengubah manajemen berbasis pusat menjadi manajemen berbasis sekolah (transisi) merupakan proses yang panjang dan melibatkan banyak pihak. Transisi ini memerlukan penyesuaian-penyesuaian, baik sistem (struktur)nya, kulturnya, maupun figurnya, dengan tuntutan-tuntutan baru manajemen berbasis sekolah. Oleh karena itu, kita tidak bermimpi bahwa perubahan ini akan berlangsung sekali jadi dan baik hasilnya. Dengan demikian, fleksibiltas dan eksperimentasi-eksperimentasi yang menghasilkan kemungkinan-kemungkinan baru dalam penyelenggaraan manajemen berbasis sekolah perlu didorong. Manajemen Berbasis Sekolah (MBS) merupakan model pengelolaan sekolah yang bertumpu pada tiga pilar utama yaitu:

1. Manajemen pengelolaan sekolah secara transfaransi dan akuntabel

2. Peran serta masyarakat atau stakeholder

3. Pembelajaran Aktif, kreatif, efektif dan menyenangkan.

\section{CATATAN AKHIR}

1. Dewan Perwakilan Rakyat, Undang-Undang Republik Indonesia Nomor 22 Tahun 1999 tentang Pemerintahan Daerah, Jakarta: Dewan Perwakilan Rakyat, 1999 dan Dewan Perwakilan Rakyat, Peraturan Pemerintah Republik Indonesia Nomor 25 Tahun 2000 tentang Kewenangan Pemerintah dan Kewenangan Propinsi Sebagai Daerah Otonomi, Jakarta: Dewan Perwakilan Rakyat, 2000.

2. Aburizal Bakrie, Mengefektifkan Sistem Pendidikan Ganda, Makalah Disampaikan pada Rapat Kerja Majelis Pendidikan Kejuruan Nasional, 29 Maret 1999 di Jakarta.

3. Poernomosidi Hadjisarosa, Naskah 1: Butir-Butir untuk Memahami Pengertian Mengenali Hal Secara Utuh dan Benar, Bahan Kuliah STIE Mitra Indonesia, 1997.

4. Dewan Perwakilan Rakyat, Undang-Undang Republik Indonesia Nomor 22 Tahun 1999 tentang Pemerintahan Daerah, op. cit.

5. William J. Bailey, School-Site Management Applied, Lancaster-Basel: Technomic Publishing CO.INC, 1991.

6. Jane L. David, Synthesis of Research on School-Based Management, (Educational Leadership, Volume 46, Number 8, May 1989).

7. Slamet PH., Menuju Pengelolaan Pendidikan Berbasis Sekolah, Makalah Disampaikann dalam Seminar Regional dengan Tema "Otonomi Pendidikan 
dan Implementasinya dalam EBTANAS" pada Tanggal 8 Mei 2000 di Universitas Panca Marga Probolinggo, Jawa Timur.

8. Slamet PH, Ibid.

9. Slamet PH, Ibid.

10. Cangeni, Joseph P. \& Casimir J. Kowalski \& Jeffry C. Claypool, Participative Management, New York: Philosophical Library, 1984.

11. Cangeni, Joseph P. \& Casimir J. Kowalski \& Jeffry C. Claypool, op. cit.

12. Poernomosidi Hadjisarosa, Naskah 1: Butir-Butir untuk Memahami Pengertian Mengenali Hal Secara Utuh dan Benar, Bahan Kuliah STIE Mitra Indonesia, 1997.

13. Slamet PH, op. cit.

\section{DAFTAR PUSTAKA}

Bakrie, Aburizal, Mengefektifkan Sistem Pendidikan Ganda, Makalah Disampaikan pada Rapat Kerja Majelis Pendidikan Kejuruan Nasional, 29 Maret 1999, di Jakarta.

Bailey, William J., School-Site Management Applied, Lancaster-Basel: Technomic Publishing CO.INC, 1991.

Direktorat Dikmenum, Manajemen Peningkatan Mutu Berbasis Sekolah, Jakarta: Depdiknas, 2000.

Bovin, Olle, Towards A Learning Organization, Geneva: International Labour Office, 2000.

Cangeni, Joseph P. \& Casimir J. Kowalski \& Jeffry C. Claypool, Participative Management, New York: Philosophical Library, 1984.

David, Jane L., Synthesis of Research on School-Based Management, Educational Leadership, Volume 46, Number 8, May 1989.

Dewan Perwakilan Rakyat, Undang-Undang Republik Indonesia Nomor 22 Tahun 1999 tentang Pemerintahan Daerah, Jakarta: Dewan Perwakilan Rakyat, 1999.

Dewan Perwakilan Rakyat, Peraturan Pemerintah Republik Indonesia Nomor 25 Tahun 2000 tentang Kewenangan Pemerintah dan Kewenangan Propinsi Sebagai Daerah Otonomi, Jakarta: Dewan Perwakilan Rakyat, 2000.

Direktorat Pendidikan Menengah Umum, Manajemen Peningkatan Mutu Berbasis Sekolah (Buku 1), Jakarta: Direktorat Pendidikan Menengah Umum, Departemen Pendidikan Nasional, 2000.

Poernomosidi Hadjisarosa, Naskah 1: Butir-Butir untuk Memahami Pengertian Mengenali Hal Secara Utuh dan Benar, (Bahan Kuliah STIE Mitra Indonesia), 1997.

Slamet PH., Menuju Pengelolaan Pendidikan Berbasis Sekolah, Makalah Disampaikann dalam Seminar Regional dengan Tema "Otonomi Pendidikan dan Implementasinya dalam EBTANAS" pada Tanggal 8 Mei 2000 di Universitas Panca Marga Probolinggo, Jawa Timur.

Slamet PH., Menuju Pengelolaan Pendidikan Berbasis Sekolah, Makalah pada Acara Seminar dan Temu Alumni Fakultas Ilmu Sosial, Universitas Negeri Yogyakarta dengan Tema "Pendidikan yang Berwawasan Pembebasan: Tantangan Masa Depan" pada Tanggal 27 Mei 2000 di Ambarukmo Palace Hotel, Yogyakarta. 